ISSN 1678-3921

Journal homepage: www.embrapa.br/pab

For manuscript submission and journal contents, access: www.scielo.br/pab

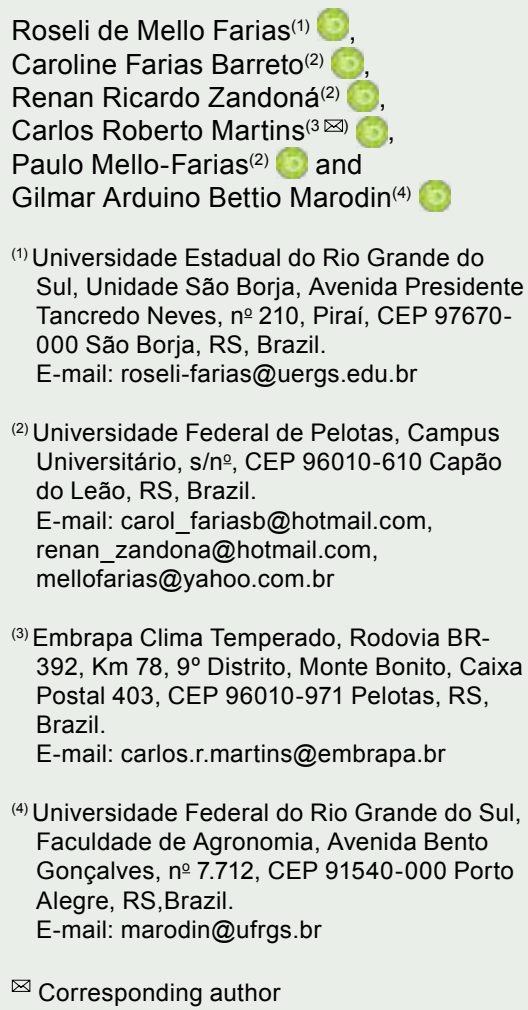

(3) Embrapa Clima Temperado, Rodovia BR$392, \mathrm{Km} 78,9^{\circ}$ Distrito, Monte Bonito, Caixa Postal 403, CEP 96010-971 Pelotas, RS, Brazil.

E-mail: carlos.r.martins@embrapa.br

(4) Universidade Federal do Rio Grande do Sul, Faculdade de Agronomia, Avenida Bento Gonçalves, no 7.712, CEP 91540-000 Porto Alegre, RS,Brazil.

\section{Chemical thinning of 'BRS Kampai' peach trees}

\begin{abstract}
The objective of this work was to evaluate the effect of thinning with metamitron on the fruit yield and quality of 'BRS Kampai' peach (Prunus persica) trees. The experiment was carried out in the municipality of Eldorado do Sul, in the state of Rio Grande do Sul, Brazil, in the 2016 and 2017 crop years. Treatments consisted of the application of 100, 200, 300, and $400 \mathrm{mg} \mathrm{L}^{-1}$ metamitron and of hand thinning 40 days after full bloom, besides control plants. Fruit abscission, effective fructification, number of fruits, and fruit yield per plant were evaluated. Regarding fruit quality, fresh fruit biomass, epidermis color, pulp firmness, soluble solids, total phenolic compounds, and antioxidant activity were assessed; fruits were also classified into diameter classes. For fruit abscission, the effect of the application of $100 \mathrm{mg} \mathrm{L}^{-1}$ metamitron is similar to that of hand thinning. Fruit yield and mean mass in all treatments with metamitron are similar to those obtained by hand thinning. The application of metamitron does not affect the fruit quality of peach trees. Chemical thinning with metamitron may be an alternative to hand thinning in peach trees used for the production of fruits for fresh consumption.
\end{abstract}

Index terms: Prunus persica, abscission, fruit quality, hand thinning, metamitron.

\section{Raleio químico em pessegueiros 'BRS Kampai'}

Resumo - O objetivo deste trabalho foi avaliar o efeito do raleio com metamitron sobre a produção e a qualidade dos frutos de pessegueiros 'BRS Kampai' (Prunus persica). O experimento foi realizado no Município de Eldorado do Sul, no Estado do Rio Grande do Sul, durante as safras de 2016 e 2017. Os tratamentos consistiram na aplicação de 100, 200, 300 e $400 \mathrm{mg} \mathrm{L}^{-1}$ de metamitron e no raleio manual aos 40 dias após a plena floração, além de plantas-testemunhas. Foram avaliados abscisão de frutos, frutificação efetiva, número de frutos e produção de frutos por planta. Em relação à qualidade dos frutos, avaliaram-se biomassa fresca, coloração da epiderme, firmeza de polpa, sólidos solúveis, compostos fenólicos totais e atividade antioxidante; os frutos também foram classificados em classes de calibre. Quanto à abscisão de frutos, o efeito da aplicação de $100 \mathrm{mg} \mathrm{L}^{-1}$ de metamitron é similar ao do raleio manual. A produção e a massa média dos frutos em todos os tratamentos com metamitron são similares às obtidas com o raleio manual. A aplicação de metamitron não influencia a qualidade dos frutos de pessegueiros. $\mathrm{O}$ raleio químico com metamitron pode ser uma alternativa ao raleio manual em pessegueiros usados para produção de frutos para consumo fresco.

Termos para indexação: Prunus persica, abscisão, qualidade dos frutos, raleio manual, metamitron. 


\section{Introduction}

The high fructification of peach trees results in an excessive number of fruits, which are usually small and have a low commercial value (Giovanaz et al., 2016). To improve the quality of fruits for fresh consumption and increase their market value, as well as to mitigate production alternance, thinning is the practice commonly adopted (Costa et al., 2013; Greene \& Costa, 2013). It is often carried out in peachgrowing regions, mainly manually, between 40 and 50 days after full bloom (Meitei et al., 2013; Petri et al., 2016; Oliveira et al., 2017). However, it demands much workforce in a short period and, consequently, has a high cost (McArtney et al., 2012; Simões et al., 2013).

Therefore, to reach a new economically viable level of peach production, alternatives to hand thinning are necessary. Chemical thinning is one of them, since it is fast acting and allows the use of different products, leading to a decrease in required costs and time. However, the success of this practice depends on the environmental conditions of the region, the genetic characteristics of the grown cultivar, the used concentration of the product and the appropriate phenological moment for its application (Brunner, 2014; McArtney \& Obermiller, 2014).

Some chemical substances have been studied for fruit thinning of apple (Petri et al., 2016; Gabardo et al., 2017; Goulart et al., 2017;) and peach (McArtney et al., 2012; Meitei et al., 2013; Giovanaz et al., 2014, 2016) trees, and metamitron has stood out among them. In apple trees, it has shown satisfactory results in fruit thinning by inhibiting photosynthesis (Petri et al., 2016; Gabardo et al., 2017; Goulart et al., 2017). In 'Contender' peach trees, however, the application of 100 to $400 \mathrm{mg} \mathrm{L}^{-1}$ metamitron did not show satisfactory results for chemical thinning (McArtney et al., 2012), whereas $100 \mathrm{mg} \mathrm{L}^{-1}$ metamitron applied to 'Maciel' peach trees close to full bloom acted similarly to manual thinning (Farias et al., 2019).

When applied to fruit trees, metamitron contributes to fruit fall. According to several authors (Barber, 2001; Formaggio et al., 2001; Basak, 2011; Stern, 2014), the substance acts on photosystem II as an inhibitor of electron transfer from plastoquinone QA to QB in the chloroplast. This blockage leads to the formation of chlorophyll in a higher energetic state (triplet chlorophyll), which may react with molecular oxygen, yield singlet oxygen, and cause lipid peroxidation and damage to protein and pigments, besides the photoinhibition of the photosynthetic apparatus. This photoinhibition decreases the production of adenosine triphosphate and nicotinamide adenine dinucleotide phosphate, as well as $\mathrm{CO}_{2}$ fixation, limiting the production of carbohydrates and the synthesis of sucrose and starch by the plant (Hugie et al., 2008).

Despite these researches, there is still little knowledge of chemical thinning in peach tree crops in the South of Brazil and specifically of the use and effectiveness of metamitron as a thinning agent.

The objective of this work was to evaluate the effect of thinning with metamitron on the fruit yield and quality of 'BRS Kampai' peach trees.

\section{Materials and Methods}

The experiment was carried out at a peach orchard at the experimental station of Universidade Federal do

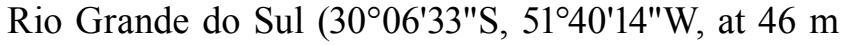
altitude), in the municipality of Eldorado do Sul, in the state of Rio Grande do Sul, Brazil, in the 2016 and 2017 crop years. The soil of the region is classified as an Argilossolo Vermelho distrófico típico (Santos et al., 2013), i.e., a Rhodic Ultisol. According to Köppen's classification, the climate is $\mathrm{Cfa}$, humid temperate, with a hot summer.

The evaluated cultivar was BRS Kampai [Prunus persica (L.) Batsch]. It is characterized by a low-acidity white pulp and by a precocious maturation, being harvested starting in the first fortnight of November in the state of Rio Grande do Sul; in the subtropical region of Brazil, including the states of São Paulo, Minas Gerais, and Espírito Santo, low chill allows for its normal germination and flowering (Raseira et al., 2014).

At the experimental orchard, six-year-old 'BRS Kampai' peach trees had been grafted onto 'Capdeboscq' rootstocks. Plants were trained to the open-vase system, using four to six primary branches or scaffolds, on which the productive branches are located; primary branches are emitted from nearby trunk points about 30 to $50 \mathrm{~cm}$ from the ground. Spacing between rows and plants was 5.5 and $2.5 \mathrm{~m}$, respectively.

The experimental design was a randomized complete block, with five replicates, each plant being considering an experimental unit of one plant. The treatments consisted of: plants with high fructification 
subjected to chemical thinning with $100,200,300$, and $400 \mathrm{mg} \mathrm{L}^{-1}$ metamitron and to hand thinning 40 days after full bloom (DAFB), which occurred on 7/16/2016 and $7 / 26 / 2017$; and control plants, without thinning. Goltix (Adama Agan Ltd., Ashdod, Israel), with 70\% active ingredient, was the source of metamitron, and 0.05\% Silwet L-77 (Momentive Performance Materials USA, INC, Friendly, WV, USA), a nonionic surfactant, was added to all treatments. Solutions were prepared on the field right before they were applied with the Jacto PJH backpack pulverizer (Jacto, Pompéia, SP, Brazil) at a working pressure of 40 psi. Hand thinning was performed to leave from 10 to $15 \mathrm{~cm}$ between fruits on peach tree branches, depending on plant vigor. It should be noted that no hand thinning was carried out during the chemical thinning treatments.

Fruit abscission (\%) was obtained by randomly choosing five branches in every peach tree, marking them, and counting the number of fruits, both before the treatments and at harvest time. Effective fructification (\%) was determined on those five branches per plant by counting the number of flowers at full bloom and the number of fruits at harvest time. The number of fruits per plant was obtained by counting fruits at harvest time and was used to determine fruit yield per plant (kg per plant).

Fruits were harvested on 11/11/2016, at 118 DAFB, and on 11/9/2017, at 106 DAFB, only once each year. After harvest, a 50-fruit sample per replicate was taken to the Fruit Laboratory of Universidade Federal de Pelotas, located in the municipality of Pelotas, also in the state of Rio Grande do Sul, to evaluate: mean fresh fruit biomass, determined by weighing fruit on a digital scale, with results expressed in grams; and fruit diameter, classified into four categories $(>70 \mathrm{~mm}$, from 70 to $60 \mathrm{~mm}$, from 60 to $50 \mathrm{~mm}$, and $<50 \mathrm{~mm}$ ).

A 20-fruit sample per replicate was collected for physicochemical and bioactive compound analyses. The color of peach epidermis, expressed as Hue angle, was analyzed at the equatorial region of the fruits using the CR-300 chroma meter (Konica Minolta Business Solutions do Brasil Ltda., São Paulo, SP, Brazil) with a D65 light source. Pulp firmness was measured on two opposite sides of the equatorial region of the fruits with no skin, using the 53205 digital fruit firmness tester (T.R. Turoni srl, Forlì, Italy), with an 8-mm tip, and results were expressed as Newtons. Soluble solid contents were obtained by the PAL-1 digital refractometer (Atago Brasil Ltda., Ribeirão Preto, SP, Brazil), and results were expressed as ${ }^{\circ}$ Brix.

To determine the bioactive compounds of peach pulp, two analyses were carried out. Total phenolic compounds were determined based on their reaction with the Folin-Ciocalteu reagent, as adapted from Singleton \& Rossi (1965); results were expressed as milligrams of gallic acid equivalent per $100 \mathrm{~g}$ sample. Antioxidant activity was obtained by the 2,2-diphenyl1-picrylhydrazyl free radical method, adapted from Brand-Williams et al. (1995); results were expressed as $\mathrm{mg}$ of Trolox equivalent per $100 \mathrm{~g}$ fresh weight.

Data were evaluated for normality by the ShapiroWilk test and for homoscedasticity by Hartley's test, being subjected to the analysis of variance, at 5\% probability, afterwards. When statistical significance was found for metamitron concentrations, polynomial regression was used. In addition, when there was statistical significance, treatments were compared by the following orthogonal contrasts, at 5\% probability: $\mathrm{C} 1$, control vs. chemical thinning process (hand thinning vs. $100,200,300$, and $400 \mathrm{mg} \mathrm{L}^{-1}$ metamitron); and $\mathrm{C} 2$, hand thinning vs. metamitron concentrations. Contrasts were considered significant when $p \leq 0.05$ in the F-test. The Sisvar software, version 5.6, was used for the statistical analysis (Ferreira, 2014).

\section{Results and Discussion}

The application of metamitron had a thinning effect on fruits in the 2016 and 2017 crop seasons, i.e., fruit abscission occurred when the concentration of 100 $\mathrm{mg} \mathrm{L}^{-1}$ metamitron or higher was applied (Table 1), resulting in an ascending linear regression. These results corroborate those reported by Brunner (2014), Greene (2014), and Gabardo et al. (2017), who found that the increase in the concentrations of metamitron for apple tree thinning caused a greater fruit fall.

As previously mentioned, metamitron acts on photosystem II by inhibiting electron transport (Basak, 2011; Stern, 2014). This reduces fruit quantity, possibly due to the direct action of the substance on photosynthetic inefficiency, which reduces the production of carbohydrates required for fruit fixation (Farias et al., 2019).

The effective fructification of peach trees in both experimental years was not affected by the different metamitron concentrations (Table 1). In C1, 
control plants altered fruit abscission and effective fructification in both crop seasons; however, in $\mathrm{C} 2$, hand thinning showed the same behavior as chemical thinning with metamitron for fruit abscission and effective fructification, but only in 2017.

Fruit yield and number per plant responded to metamitron concentrations following a descending linear regression in the 2016 and 2017 crop seasons (Table 2). Therefore, the increase in metamitron concentrations led to a decrease in fruit yield and number per plant. These results are similar to those of Farias et al. (2019), who found that high metamitron concentrations increased the average mass of 'Maciel' peach fruits, reducing the number of fruits per plant. Furthermore, concentrations of metamitron higher than $200 \mathrm{mg} \mathrm{L}^{-1}$ were phytotoxic to 'Contender' peach leaves, reducing their chlorophyll content (McArtney \& Obermiller, 2012).

Fruit yield per plant decreased as metamitron concentrations increased in both crop seasons, probably because of the strong thinning effect of the substance and the consequent small fruit load. Similar

Table 1. Fruit abscission and set of 'BRS Kampai' peach (Prunus persica) trees subjected to chemical thinning with metamitron and to hand thinning in the municipality of Eldorado do Sul, in the state of Rio Grande do Sul, Brazil, in the 2016 and 2017 crop seasons.

\begin{tabular}{|c|c|c|c|c|}
\hline \multirow{2}{*}{$\begin{array}{l}\text { Metamitron } \\
\text { concentration }\left(\mathrm{mg} \mathrm{L}^{-1}\right)\end{array}$} & \multicolumn{2}{|c|}{ Fruit abscission (\%) } & \multicolumn{2}{|c|}{ Fruit set (\%) } \\
\hline & 2016 & 2017 & 2016 & 2017 \\
\hline 0 & 34.87 & 32.61 & 42.20 & 28.05 \\
\hline 100 & 62.36 & 72.96 & 35.37 & 19.40 \\
\hline 200 & 59.30 & 71.33 & 34.89 & 23.31 \\
\hline 300 & 69.06 & 71.06 & 25.62 & 23.46 \\
\hline 400 & 65.96 & 73.65 & 28.33 & 19.86 \\
\hline $\mathrm{CV}(\%)$ & 16.68 & 10.91 & 27.52 & 26.28 \\
\hline Linear & $*(1)$ & $*(2)$ & ns & ns \\
\hline Quadratic & ns & ns & ns & ns \\
\hline Hand thinning $^{(3)}$ & 81.29 & 74.86 & 14.46 & 18.46 \\
\hline \multicolumn{5}{|l|}{ Contrasts $^{(4)}$} \\
\hline $\mathrm{C} 1$ & $*$ & $*$ & $*$ & $*$ \\
\hline $\mathrm{C} 2$ & $*$ & ns & $*$ & ns \\
\hline \multicolumn{5}{|c|}{$\begin{array}{l}\left({ }^{(1)} \mathrm{y}=49.914+0.052 \mathrm{x} ; \mathrm{R}^{2}=0.7671 .{ }^{(2)} \mathrm{y}=54.286+0.0602 \mathrm{x} ; \mathrm{R}^{2}=0.5118 .\right. \\
{ }^{\left({ }^{3}\right)} \text { Performed } 40 \text { days after full bloom. }{ }^{\left({ }^{(}\right)} \mathrm{C} 1 \text {, control vs. chemical thinning } \\
\text { process (hand thinning vs. metamitron concentrations); and } \mathrm{C} 2 \text {, hand } \\
\text { thinning vs. metamitron concentrations. }{ }^{*} \text { Significant at } 5 \% \text { probability. } \\
\text { ns Nonsignificant. }\end{array}$} \\
\hline
\end{tabular}

results were reported by Moyano et al. (2011) and ElBoray et al. (2013), who verified low peach yields in chemically-thinned plants due to a decrease in the number of fruits. In $\mathrm{C} 1$, control plants influenced peach yield and affected the number of fruits in both crop seasons. However, in $\mathrm{C} 2$, hand thinning had the same behavior as chemical thinning with the different metamitron concentrations for fruit yield per plant in 2016 and 2017 and for number of fruits in 2017.

No significant differences were observed for mean fresh fruit biomass in relation to metamitron concentrations in the first crop season (Table 2). However, in the second one, this trait resulted in a quadratic convex regression: the lowest and highest mean mass were found with 150 and $400 \mathrm{mg} \mathrm{L}^{-1}$ metamitron, respectively. According to Brunner (2014), high metamitron concentrations cause an increase in mean apple mass. In $\mathrm{C} 1$, control plants affected mean fruit mass in 2016, whereas, in C2, hand thinning and thinning with metamitron behaved similarly in both studied crop seasons.

Table 2. Yield per plant, number of fruits per plant, and mean fresh fruit biomass of 'BRS Kampai' peach (Prunus persica) trees subjected to chemical thinning with metamitron and to hand thinning in the municipality of Eldorado do Sul, in the state of Rio Grande do Sul, Brazil, in the 2016 and 2017 crop seasons.

\begin{tabular}{|c|c|c|c|c|c|c|}
\hline \multirow{2}{*}{$\begin{array}{l}\text { Metamitron } \\
\text { concentration } \\
\left(\mathrm{mg} \mathrm{L}^{-1}\right)\end{array}$} & \multicolumn{2}{|c|}{$\begin{array}{l}\text { Yield per } \\
\text { plant }(\mathrm{kg})\end{array}$} & \multicolumn{2}{|c|}{$\begin{array}{c}\text { Number of fruits } \\
\text { per plant }\end{array}$} & \multicolumn{2}{|c|}{$\begin{array}{l}\text { Mean fresh fruit } \\
\text { biomass }(\mathrm{g})\end{array}$} \\
\hline & 2016 & 2017 & 2016 & 2017 & 2016 & 2017 \\
\hline 0 & 65.27 & 42.37 & 696.40 & 438.20 & 93.76 & 96.73 \\
\hline 100 & 55.26 & 38.86 & 512.20 & 416.60 & 107.98 & 93.36 \\
\hline 200 & 45.48 & 35.55 & 427.00 & 374.80 & 106.56 & 95.10 \\
\hline 300 & 48.57 & 39.40 & 476.00 & 404.20 & 102.05 & 97.40 \\
\hline 400 & 39.94 & 36.35 & 386.80 & 332.40 & 103.32 & 109.42 \\
\hline $\begin{array}{ll}\mathrm{CV}(\%) \\
\end{array}$ & 10.02 & 15.51 & 11.67 & 9.32 & 9.45 & 8.29 \\
\hline Linear & $*(1)$ & $*(2)$ & $*(3)$ & $*(4)$ & ns & ns \\
\hline Quadratic & ns & ns & ns & $\mathrm{ns}$ & $\mathrm{ns}$ & $*(5)$ \\
\hline Hand thinning $^{(6)}$ & 44.97 & 35.70 & 410.00 & 362.00 & 109.70 & 103.96 \\
\hline \multicolumn{7}{|l|}{ Contrasts $^{(7)}$} \\
\hline $\mathrm{C} 1$ & * & $*$ & $*$ & $*$ & $*$ & ns \\
\hline $\mathrm{C} 2$ & $\mathrm{~ns}$ & $\mathrm{~ns}$ & $*$ & ns & ns & ns \\
\hline \multicolumn{7}{|c|}{ 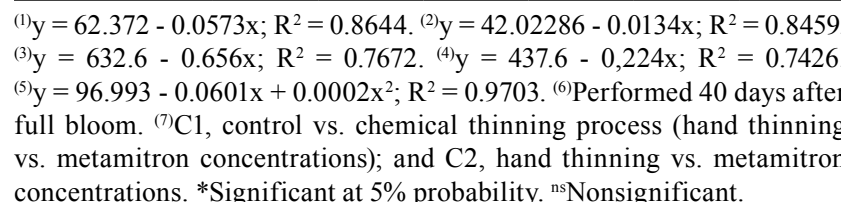 } \\
\hline
\end{tabular}


Regarding fruit quality, metamitron did not interfere in fruit color (Table 3). Therefore, no significant differences were found among metamitron concentrations or in the tested contrasts in both crop seasons. This result is interesting since the color of fruit epidermis, especially red, is the main quality parameter influencing consumer acceptance (Li et al., 2002).

Pulp firmness did not differ significantly among metamitron concentrations in 2016. However, a quadratic regression was observed in 2017, when the highest pulp firmness of $27 \mathrm{~N}$ was obtained with 173 mg L $\mathrm{L}^{-1}$ metamitron (Table 3). Therefore, each crop season behaved differently regarding this variable. Fruit size reflects, in addition to environmental conditions for cultivation, the number or load of fruits on the plant, which directly influence it and also plant nutrition, especially in relation to nitrogen fertilization. The results of the present study agree with those of Raseira et al. (2014), who reported an average pulp firmness from 22 to $35 \mathrm{~N}$ for the same cultivar. In $\mathrm{C} 1$, the pulp firmness of fruits from plants that had not been thinned was altered in 2017. In C2, in both evaluated crop seasons, hand-thinning affected the pulp firmness of peaches.

Concerning soluble solids contents, there was no significant difference among metamitron concentrations in both crop seasons (Table 3). The obtained results are in alignment with those described by Raseira et al. (2010), who found mean values ranging from 9 to $13^{\circ}$ Brix. In $\mathrm{C} 1$, control plants and thinned plants showed the same behavior regarding soluble solid contents in 2016 and 2017. However, in C2, the soluble solid contents of hand-thinned plants was altered in both crop seasons. It should be highlighted that no direct relationship could be established between both thinning methods, since physiological responses differed depending on the crop. The cause of this behavior was not clearly determined, but it is known that the content of soluble solids may be associated with other management factors, such as the position of fruits in the plant, light penetration through the crown, and interaction between irrigation and exposure to sunlight (Picolotto et al., 2009; Alcobendas et al., 2013). Soluble solid contents are also related to plant nutrition, mainly regarding nitrogen and potassium fertilization, and the application of potassium (via soil or leaf) near fruit harvesting generally increases fruit color and sweetness (Jawandha et al., 2017; Solhjoo et al., 2017). The yield and quality of peach fruits were affected by texture, water content, organic matter, exchangeable potassium and magnesium (Oldoni et al., 2019). In another study, the application of potassium to 'Flordastar' peach

Table 3. Epidermis color, pulp firmness, and soluble solid contents of 'BRS Kampai' peach (Prunus persica) fruits from trees subjected to chemical thinning with metamitron and to hand thinning in the municipality of Eldorado do Sul, in the state of Rio Grande do Sul, Brazil, in the 2016 and 2017 crop seasons.

\begin{tabular}{|c|c|c|c|c|c|c|}
\hline \multirow{2}{*}{$\begin{array}{l}\text { Metamitron concentration } \\
\left(\mathrm{mg} \mathrm{L}^{-1}\right)\end{array}$} & \multicolumn{2}{|c|}{ Epidermis color $\left({ }^{\circ} \mathrm{Hue}\right)$} & \multicolumn{2}{|c|}{ Pulp firmness (N) } & \multicolumn{2}{|c|}{ Soluble solids $\left({ }^{\circ}\right.$ Brix $)$} \\
\hline & 2016 & 2017 & 2016 & 2017 & 2016 & 2017 \\
\hline 0 & 85.63 & 80.93 & 26.44 & 25.60 & 9.86 & 11.64 \\
\hline 100 & 83.73 & 85.29 & 24.62 & 32.65 & 10.04 & 10.60 \\
\hline 200 & 88.85 & 85.82 & 24.48 & 28.61 & 9.92 & 10.42 \\
\hline 300 & 87.47 & 88.31 & 26.73 & 28.48 & 10.24 & 13.50 \\
\hline 400 & 86.56 & 80.61 & 26.78 & 27.44 & 10.38 & 12.74 \\
\hline CV (\%) & 3.03 & 13.97 & 7.85 & 6.69 & 4.33 & 6.17 \\
\hline Linear & ns & ns & ns & ns & ns & ns \\
\hline Quadratic & $\mathrm{ns}$ & $\mathrm{ns}$ & $\mathrm{ns}$ & $*(1)$ & $\mathrm{ns}$ & ns \\
\hline Hand thinning ${ }^{(2)}$ & 87.38 & 84.69 & 22.20 & 25.04 & 9.06 & 12.92 \\
\hline \multicolumn{7}{|l|}{ Contrasts $^{(3)}$} \\
\hline $\mathrm{C} 1$ & $\mathrm{~ns}$ & $\mathrm{~ns}$ & $\mathrm{~ns}$ & $*$ & $\mathrm{~ns}$ & ns \\
\hline $\mathrm{C} 2$ & $\mathrm{~ns}$ & $\mathrm{~ns}$ & $*$ & $*$ & $*$ & $*$ \\
\hline
\end{tabular}

${ }^{(1)} \mathrm{y}=26.9011+0.0346 \mathrm{x}-0.0001 \mathrm{x}^{2} ; \mathrm{R}^{2}=0.4029 .{ }^{(2)}$ Performed 40 days after full bloom. ${ }^{(3)} \mathrm{C} 1$, control vs. chemical thinning process (hand thinning vs. metamitron concentrations); and $\mathrm{C} 2$, hand thinning vs. metamitron concentrations. ${ }^{*}$ Significant at $5 \%$ probability. ${ }^{\text {ns Nonsignificant. }}$ 
increased total soluble solid contents, but did not affect total acidity; consequently, the soluble solids/titratable acidity ratio followed the same response as that of total soluble solids (Dbara et al., 2016).

Total phenolic contents and antioxidant activity did differ significantly in the pulp of peaches from trees subjected to chemical thinning in 2016 (Table 4). In 2017, total phenolic content and antioxidant activity showed a descending linear response to metamitron concentrations, i.e., the more the metamitron concentrations increased, the more the bioactive compounds in the peach pulp decreased. Both in $\mathrm{C} 1$ and $\mathrm{C} 2$, the thinning methods did not affect total phenolic contents of the peach pulp. In $\mathrm{Cl}$, control plants affected antioxidant activity in 2016, and, in $\mathrm{C} 2$, hand-thinned plants altered the antioxidant activity of peaches in both crop years.

In general, the factors evaluated for peach quality were inconsistent among fruit-thinning treatments. Moreover, fruit quality characteristics were better

Table 4. Total phenolic contents and antioxidant activity of the pulp of 'BRS Kampai' peach (Prunus persica) fruits from trees subjected to chemical thinning with metamitron and to hand thinning in the municipality of Eldorado do Sul, in the state of Rio Grande do Sul, Brazil, in the 2016 and 2017 crop seasons.

\begin{tabular}{|c|c|c|c|c|}
\hline \multirow{2}{*}{$\begin{array}{l}\text { Metamitron } \\
\text { concentration }\left(\mathrm{mg} \mathrm{L}^{-1}\right)\end{array}$} & \multicolumn{2}{|c|}{ Total phenols $^{(1)}$} & \multicolumn{2}{|c|}{ Antioxidant activity ${ }^{(2)}$} \\
\hline & 2016 & 2017 & 2016 & 2017 \\
\hline 0 & 75.43 & 46.05 & 238.54 & 188.98 \\
\hline 100 & 99.66 & 49.39 & 275.97 & 199.82 \\
\hline 200 & 62.97 & 38.96 & 136.10 & 165.92 \\
\hline 300 & 62.26 & 36.43 & 466.36 & 138.92 \\
\hline 400 & 67.25 & 38.29 & 243.00 & 154.26 \\
\hline CV (\%) & 17.32 & 17.23 & 10.2 & 9.51 \\
\hline Linear & ns & $*(3)$ & ns & $*(4)$ \\
\hline Quadratic & ns & ns & ns & ns \\
\hline Hand thinning ${ }^{(5)}$ & 80.09 & 45.68 & 480.88 & 240.18 \\
\hline \multicolumn{5}{|l|}{ Contrasts $^{(6)}$} \\
\hline $\mathrm{C} 1$ & ns & ns & $*$ & ns \\
\hline $\mathrm{C} 2$ & ns & ns & $*$ & * \\
\hline
\end{tabular}

(1) $\mathrm{mg}$ Gallic acid equivalent per $100 \mathrm{~g}^{-1}$ fresh weight. ${ }^{(2)} \mathrm{mg}$ equivalent Trolox per $100 \mathrm{~g}^{-1}$ fresh weight. ${ }^{(3)} \mathrm{y}=-47.518+0.0285 \mathrm{x} ; \mathrm{R}^{2}=0.6495$. ${ }^{(4)} \mathrm{y}=195.65-0.1303 \mathrm{x} ; \mathrm{R}^{2}=0.6853$. ${ }^{(5)}$ Performed 40 days after full bloom. ${ }^{(6)} \mathrm{C} 1$, control vs. chemical thinning process (hand thinning vs. metamitron concentrations); and $\mathrm{C} 2$, hand thinning vs. metamitron concentrations. *Significant at $5 \%$ probability. ${ }^{\text {ns }}$ Nonsignificant. correlated with conditions related to the environment and crops than with treatments using chemical thinning.

All treatments resulted in a high frequency of fruits in the diameter classes between 50 and $60 \mathrm{~mm}$ and from 60 to $70 \mathrm{~mm}$, in both the 2016 and 2017 crop seasons (Figure 1). The highest frequency of fruits in the diameter class of $<50 \mathrm{~mm}$ was found for the control plants, being 7.20 and $8.60 \%$ in 2016 and 2017,
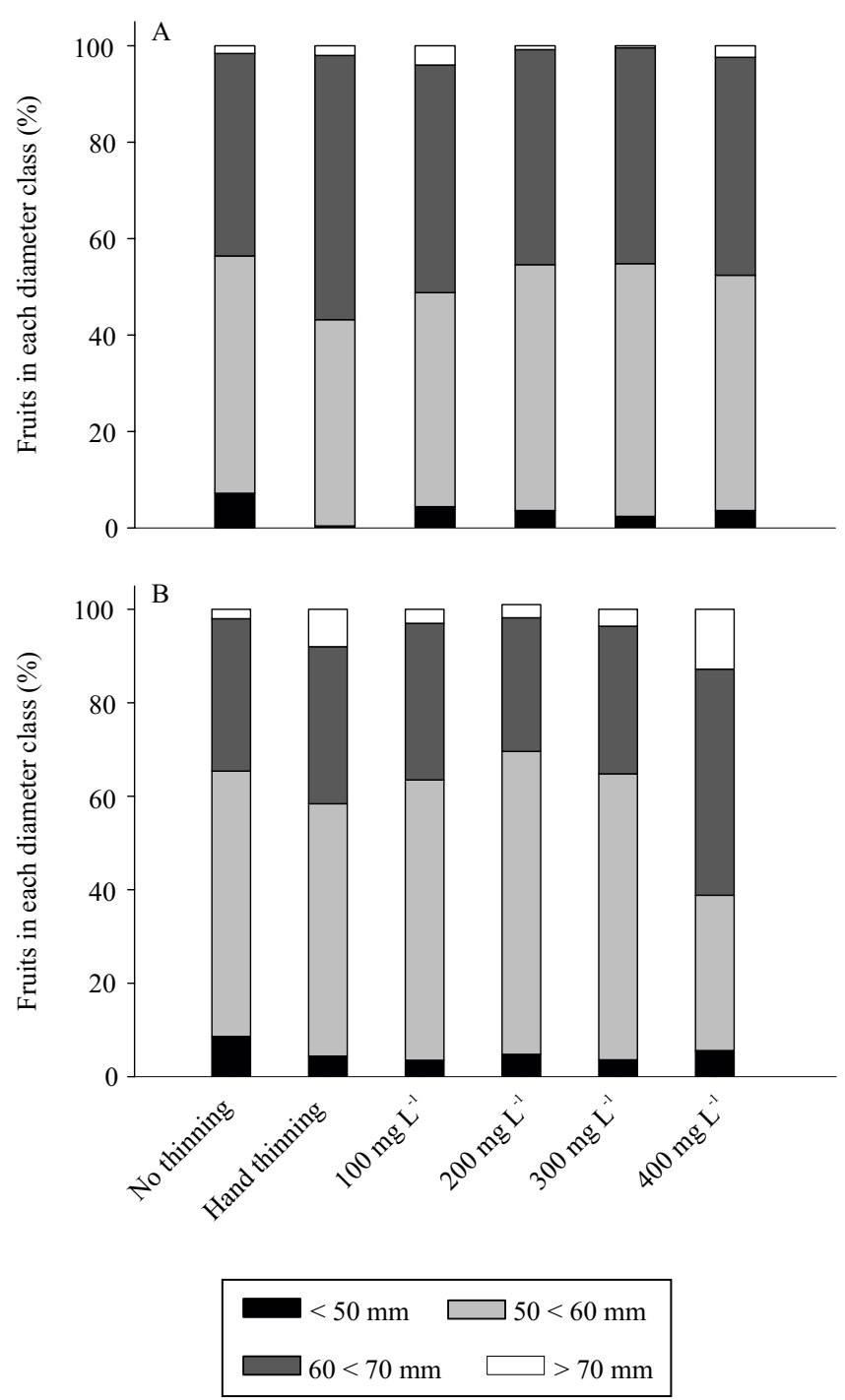

Figure 1. Diameter classes of 'BRS Kampai' peach (Prunus persica) fruits from trees subjected to no thinning, to hand thinning, and to chemical thinning with different metamitron concentrations $\left(100,200,300\right.$, and $\left.400 \mathrm{mg} \mathrm{L}^{-1}\right)$ in the municipality of Eldorado do Sul, in the state of Rio Grande do Sul, Brazil, in the 2016 (A) and 2017 (B) crop seasons. 
respectively. In 2017, the frequency of fruits whose diameters ranged between 60 and $70 \mathrm{~mm}$ decreased, in comparison with the previous crop. In this crop, plants thinned with $400 \mathrm{mg} \mathrm{L}^{-1}$ metamitron had a high distribution of fruits with diameters above $70 \mathrm{~mm}$, corresponding to $12.8 \%$ of the fruit, while plants with no thinning represented only $2 \%$ of this class.

\section{Conclusions}

1. The application of metamitron has a thinning effect on 'BRS Kampai' peach (Prunus persica) trees.

2. Regarding fruit abscission, the concentration of $100 \mathrm{mg} \mathrm{L}^{-1}$ metamitron has a similar effect to that of hand thinning.

3. Chemical thinning with $100 \mathrm{mg} \mathrm{L}^{-1}$ metamitron results in a similar fruit yield and mean mass to those achieved by hand thinning.

4. Fruit quality, especially epidermis color, is not affected by chemical thinning with metamitron.

\section{References}

ALCOBENDAS, R.; MIRÁS-AVALOS, J.M.; ALARCÓN, J.J.; NICOLÁS, E. Effects of irrigation and fruit position on size, colour, firmness and sugar contents of fruits in a mid-late maturing peach cultivar. Scientia Horticulturae, v.164, p.340347, 2013. DOI: https://doi.org/10.1016/j.scienta.2013.09.048.

BARBER, J. The structure of photosystem I. Nature Structural Biology, v.8, p.577-579, 2001. DOI: https://doi.org/10.1038/89597.

BASAK, A. Efficiency of fruitlet thinning in apple 'Gala Must' by use of metamitron and artificial shading. Journal of Fruit and Ornamental Plant Research, v.19, p.51-62, 2011.

BRAND-WILLIAMS, W.; CUVELIER, M.E.; BERSET, C. Use of a free radical method to evaluate antioxidant activity. Food Science and Technology, v.28, p.25-30, 1995. DOI: https://doi.org/10.1016/S0023-6438(95)80008-5.

BRUNNER, P. Impact of metamitron as a thinning compound on apple plants. Acta Horticulturae, v.1042, p.173-181, 2014. DOI: https://doi.org/10.17660/ActaHortic.2014.1042.21.

COSTA, G.; BLANKE, M.M.; WIDMER, A. Principles of thinning in fruit tree crops - needs and novelties. Acta Horticulturae, v.998, p.17-26, 2013. DOI: https://doi.org/10.17660/ ActaHortic.2013.998.1.

DBARA, S.; GADER, T.; BEN MIMOUN, M. Improving yield and fruit quality of peach cv. 'Flordastar' by potassium foliar spray associated to regulated deficit irrigation. Journal of New Sciences, Agriculture and Biotechnology, v.28, p.1631-1637, 2016.

EL-BORAY, M.S.; SHALAN, A.M.; KHOURI, Z.M. Effect of different thinning techniques on fruit set, leaf area, yield and fruit quality parameters of Prunus persica, L. Batsch cv. Floridaprince. Trends in Horticultural Research, v.3, p.1-13, 2013. DOI: https://doi.org/10.3923/thr.2013.1.13.

FARIAS, R. de M.; MARTINS, C.R.; BARRETO, C.F.; GIOVANAZ, M.A.; MALGARIM, M.B.; MELLO-FARIAS, P. Time of metamitron application and concentration in the chemical thinning of 'Maciel' peach. Revista Brasileira de Fruticultura, v.41, e-017, 2019. DOI: https://doi.org/10.1590/0100-29452019017.

FERREIRA, D.F. Sisvar: a guide for its bootstrap procedures in multiple comparisons. Ciência e Agrotecnologia, v.38, p.109-112, 2014. DOI: https://doi.org/10.1590/S1413-70542014000200001.

FORMAGGIO, E.; CINQUE, G.; BASSI, R. Functional architecture of the major light-harvesting complex from higher plants. Journal of Molecular Biology, v.314, p.1157-1166, 2001. DOI: https://doi.org/10.1006/jmbi.2000.5179.

GABARDO, G.C.; PETRI, J.L.; HAWERROTH, F.J.; COUTO, M.; ARGENTA, L.C.; KRETZSCHMAR, A.A. Use of metamitron as an apple thinner. Revista Brasileira de Fruticultura, v.39, e-514, 2017. doi: https://doi.org/10.1590/0100-29452017514.

GIOVANAZ, M.A.; FACHINELLO, J.C.; GOULART, C.; RADÜNZ, A.L.; AMARAL, P.A.; WEBER, D. Produção e qualidade de pêssegos, cv. Jubileu, com uso de fitorreguladores. Revista Ceres, v.61, p.552-557, 2014. DOI: https://doi.org/10.1590/0034-737X201461040015.

GIOVANAZ, M.A.; FACHINELLO, J.C.; SPAGNOL, D.; WEBER, D.; CARRA, B. Gibberellic acid reduces flowering and time of manual thinning in 'Maciel' peach trees. Revista Brasileira de Fruticultura, v.38, e-692, 2016. DOI: https://doi.org/10.1590/0100-29452016692.

GOULART, G.; ANDRADE, S.B. de; BENDER, A.; SHIAVON, A.V.; AGUIAR, G.A.; MALGARIM, M.B. Metamitron and different plant growth regulators combinations in the chemical thinning of 'Eva' apple trees. Journal of Experimental Agriculture International, v.18, p.1-6, 2017. DOI: https://doi.org/10.9734/JEAI/2017/36809.

GREENE, D.; COSTA, G. Fruit thinning in pome- and stonefruit: state of the art. Acta Horticulturae, v.998, p.93-102, 2013. DOI: https://doi.org/10.17660/ActaHortic.2013.998.10.

GREENE, D.W. Use of metamitron alone and in combination with 6-benzyladenine for thinning apples. Acta Horticulturae, v.1042, p.167-172, 2014. DOI: https://doi.org/10.17660/ ActaHortic.2014.1042.20

HUGIE, J.A.; BOLLERO, G.A.; TRANEL, P.J.; RIECHERS, D.E. Defining the rate requirements for synergism between mesotrione and atrazine in redroot pigweed (Amaranthus retroflexus). Weed Science, v.56, p.265-270, 2008. DOI: https://doi.org/10.1614/WS07-128.1.

JAWANDHA, S.K.; GILL, P.P.S.; SINGH, H.; THAKUR, A. Effect of potassium nitrate on fruit yield, quality and leaf nutrients content of plum. Vegetos - An International Journal of Plant Research, v.30, p.325-328, 2017. DOI: https://doi.org/10.5958/2229-4473.2017.00090.8.

LI, Z.H.; GEMMA, H.; IWAHORI, S. Stimulation of 'Fuji' apple skin color by ethephon and phosphorus-calcium mixed compounds 
in relation to flavonoid synthesis. Scientia Horticulturae, v.94, p.193-199, 2002. DOI: https://doi.org/10.1016/S03044238(01)00363-6.

MCARTNEY, S.J.; OBERMILLER, J.D. Use of shading and the PSII inhibitor metamitron to investigate the relationship between carbohydrate balance and chemical thinner activity in apples. Acta Horticulturae, v.1042, p.27-31, 2014. DOI: https://doi.org/10.17660/ActaHortic.2014.1042.2.

MCARTNEY, S.J.; OBERMILLER, J.D.; ARELLANO, C. Comparison of the effects of metamitron on chlorophyll fluorescence and fruit set in apple and peach. HortScience, v.47, p.509-514, 2012. DOI: https://doi.org/10.21273/hortsci.47.4.509.

MEITEI, S.B.; PATEL, R.K.; DEKA, B.C.; DESHMUKH, N.A.; SINGH, A. Effect of chemical thinning on yield and quality of peach cv. Flordasun. African Journal of Agricultural Research, v.8, p.3358-3565, 2013. DOI: https://doi.org/10.5897/ AJAR2013.7058.

MOYANO, M.I.; FLORES, P.; SETA, S.; LEONE, A.; SEVERIN, C. Efecto de diferentes prácticas culturales sobre la producción, calidad y maduración de frutos de duraznero cv. Early Grande. Ciencias Agronómicas, ano11, p.7-11, 2011.

OLDONI, H.; TERRA, V.S.S.; TIMM, L.C.; REISSER JÚNIOR, C.; MONTEIRO, A.B. Delineation of management zones in a peach orchard using multivariate and geostatistical analyses. Soil \& Tillage Research, v.191, p.1-10, 2019. DOI: https://doi.org/10.1016/j.still.2019.03.008.

OLIVEIRA, P.D. de; MARODIN, G.A.B.; ALMEIDA, G.K. de; GONZATTO, M.P.; DARDE, D.C. Heading of shoots and hand thinning of flowers and fruits on 'BRS Kampai' peach trees. Pesquisa Agropecuária Brasileira, v.52, p.1006-1016, 2017. DOI: https://doi.org/10.1590/s0100-204x2017001100006.

PETRI, J.L.; COUTO, M.; GABARDO, G.C.; FRANCESCATTO, P.; HAWERROTH, F.J. Metamitron replacing carbaryl in post bloom thinning of apple trees. Revista Brasileira de Fruticultura, v.38, e-903, 2016. DOI: https://doi.org/10.1590/0100-29452016903.
PICOLOTTO, L.; MANICA-BERTO, R.; PAZIN, D.; PASA, M. da S.; SCHMITZ, J.D.; PREZOTTO, M.E.; BETEMPS, D.; BIANCHI, V.J.; FACHINELLO, J.C. Características vegetativas, fenológicas e produtivas do pessegueiro cultivar Chimarrita enxertado em diferentes porta-enxertos. Pesquisa Agropecuária Brasileira, v.44, p.583-589, 2009. DOI: https://doi.org/10.1590/ S0100-204X2009000600006.

RASEIRA, M. do C.B.; NAKASU, B.H.; UENO, B.; SCARANARI, C. Pessegueiro: cultivar BRS Kampai. Revista Brasileira de Fruticultura, v.32, p.1275-1278, 2010. DOI: https://doi.org/10.1590/S0100-29452011005000009.

RASEIRA, M. do D.B.; NAKASU, B.H.; BARBOSA, W. Cultivares: descrição e recomendação. In: RASEIRA, M. do C.B.; PEREIRA, J.F.M.; CARVALHO, F.L.C. (Ed.). Pessegueiro. Brasília: Embrapa, 2014. p.73-141.

SANTOS, H.G. dos; JACOMINE, P.K.T.; ANJOS, L.H.C. dos; OLIVEIRA, V.A. de; LUMBRERAS, J.F.; COELHO, M.R.; ALMEIDA, J.A. de; CUNHA, T.J.F.; OLIVEIRA, J.B. de. Sistema brasileiro de classificação de solos. 3.ed. rev. e ampl. Brasília: Embrapa, 2013. 353p.

SIMÕES, M.P.; VULETA, I.; BELUSIC, N. Monda mecânica de flores com equipamento electro'flor em pessegueiros da cultivar 'Rich Lady'. Revista de Ciências Agrárias, v.36, p.297-302, 2013.

SINGLETON, V.L.; ROSSI, J.A. Colorimetry of total phenolics with phosphomolybdic-phosphotungstic acid reagents. American Journal of Enology and Viticulture, v.16, p.144-158, 1965.

SOLHJOO, S.; GHARAGHANI, A.; FALLAHI, E. Calcium and potassium foliar sprays affect fruit skin color, quality attributes, and mineral nutrient concentrations of 'Red Delicious' apples. International Journal of Fruit Science, v.17, p.358-373, 2017. DOI: https://doi.org/10.1080/15538362.2017.1318734.

STERN, R.A. The photosynthesis inhibitor metamitron is an effective fruitlet thinner for 'Gala' apple in the warm climate of Israel. Scientia Horticulturae, v.178, p.163-167, 2014. DOI: https://doi.org/10.1016/j.scienta.2014.08.005. 